\title{
Reducing livestock losses from poisonous plants through grazing management
}

\author{
C.A. TAYLOR, JR., AND M.H. RALPHS
}

\begin{abstract}
Authors are research station superintendent, Texas Agricultural Experiment Station, Sonora, Texas; and range scientist, USDA / ARS Poisonous Plant Research Laboratory, Logan, Utah, respectively. Published with approval of the Director, Texas Agricultural Experiment Station as TA
\end{abstract}

\section{Abstract}

Stocking rate, multi-species grazing, and grazing systems are 3 components of grazing management that can be manipulated to minimize losses in animal production due to consumption of poisonous plants. Our study evaluated 3 case studies where either all or some of the above components of grazing management were the experimental treatments. For study 1 the grazing treatments included 3 rates of stocking; a 4-pasture, 3-herd grazing system; and combinations of different kinds of livestock that were measured for 21 years. For study 2 the grazing treatments included 2 rates of stocking, 4 different grazing systems, and combinations of either all sheep or a ratio of 3:2 cattle to sheep (au equivalents) for 11 years. Study 3 measured cattle poisoned by locoweed prior to and following the implementation of a 3-herd, 4-pasture grazing system over 6 years.

Sheep death losses to bitterweed ( Hymenoxys odorata DC.) poisoning occurred in 13 of the 21 years on continuously grazed pastures heavily stocked with sheep and only 8 years under both moderate and light stocking rates. Regardless of the stocking rate, death losses were greatest on pastures stocked with sheep only and least with the combination of livestock species on conjunction with a 4-pasture, 3-herd grazing system. Stocking rate, multi-species grazing, or grazing system seemed to have little effect on goat losses due to oak (Quercus spp.) consumption.

Cattle and sheep were not affected by sacahuista (Nolina texana wats.) in this study; however, their inclusion in the grazing herd reduced goat death losses from 5\% with goats only to $\mathbf{2 . 5}$ and $1.5 \%$ for combinations of cattle and goats and cattle, sheep, and goats, respectively.

In study 2 sheep death losses from bitterweed poisoning under continuous yearlong grazing treatments averaged $5.2 \%$ vs $3.7 \%$ for grazing treatments with some type of grazing system. Death losses were greatest under yearlong continuous grazing stocked at 10.4 ha/auy with $100 \%$ sheep and least under yearlong continuous grazing stocked at $15.2 \mathrm{ha} /$ auy with $40 \%$ sheep.

In study 3 the number of sick calves declined from $20 \%$ to about $3 \%$ with the implementation of a new graxing system. The reduction in sickness and loss was attributed to the reduction in grazing pressure and the shorter grazing season.

It is concluded that for these case studies tactical management decisions such as proper stocking rate, combinations of animal species to be grazed, and grazing system used played an important role in minimizing livestock death losses to poisonous plants.

Key Words: poisonous plants, grazing management, stocking rate

Poisonous plants have always been a component of rangelands; however, the problem has been largely increased by excessive stocking rates and poor grazing and livestock management. Live-

\footnotetext{
Manuscript accepted 28 May 1991.
}

stock generally do not select poisonous plants in harmful amounts unless the availability of alternate choices of forage is low (Stoddart and Smith 1955).

Most rangelands were over grazed during the early development of the livestock industry, resulting in range deterioration. The more productive and desirable vegetation decreased with an increase in the less palatable and poisonous plant species. This phenomenon occurred because palatable plants typically put all of their energy from photosynthesis into growth and reproduction while unpalatable species put part of their energy into compounds that discourage defoliation. The more rapid growth of palatable species gives them an advantage under light to moderate grazing. The unpalatable species have the advantage under heavy grazing because they have less competition due to death of palatable plants and they generally receive little use (Laycock 1978, Cronin et al. 1978).

Early records indicate that stocking rates in excess of $2.6 \mathrm{ha} /$ auy were common for the Edwards Plateau in the early 1900's (Youngblood 1922). Eventually, heavy grazing eliminated or severely reduced the better range plants which were replaced by less palatable, and in many instances, poisonous plants. This resulted in a decline in range condition and consequently stocking rate (Fig. 1). Currently we consider a moderate stocking rate for the western

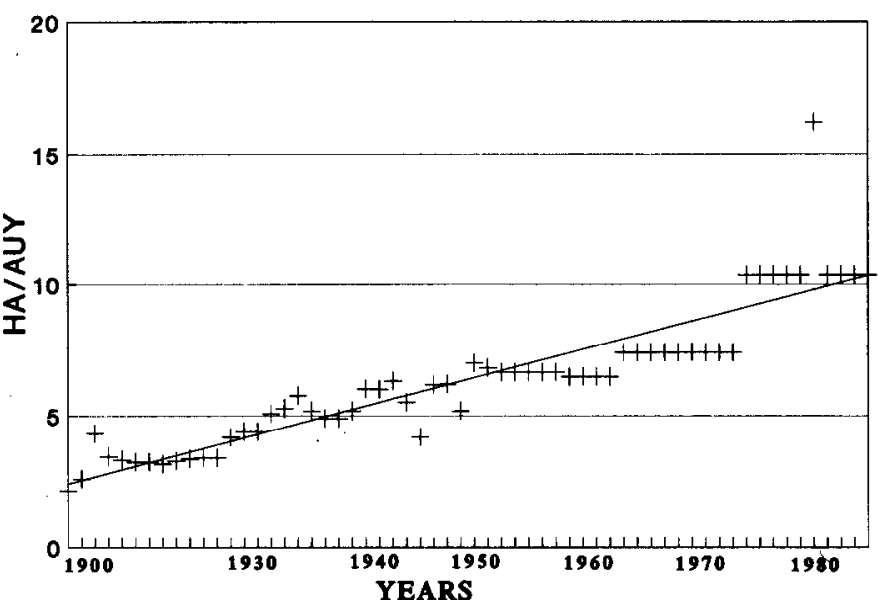

Fig. 1. Stocking rate decline on the Sonora Research Station (1900-1984). part of the Edwards Plateau to range from 13 to 8.6 ha/auy, depending on weather conditions and brush cover.

There are many plants capable of producing toxic metabolites, including palatable plants that are often important in livestock diets (Sperry et al. 1964). Because of this, both researchers and ranchers have long recognized that grazing management, "the manipulation of livestock to obtain a desired result", can play an important role in reducing livestock deaths to poisonous plants.

A major part of grazing management involves decisions on 
stocking rate, livestock species grazed (multi-species grazing), and type of grazing system used. Stocking rate is defined as the amount of land allocated to each animal unit for the entire grazable period of the year (Society for Range Management 1974). Stocking rate probably has more influence on vegetation and livestock productivity than the other 2 grazing factors.

Multi-species grazing, the use of rangelands by more than 1 species of animal, has been advocated as a range management tool for over 50 years (Stoddart and Smith 1943). Research indicates that it can optimize the transfer of nutrients from vegetation to animal products (Taylor 1985).

Rangeland grazing systems were initially developed to provide periodic rests to allow the more preferred plants to recover from defoliation. Early strategies placed more emphasis on range improvement than on animal performance. When properly managed, grazing systems can reduce the incidence of poisoning in grazing animals by providing the opportunity for management that may either avoid or reduce toxic plant problems.

The objective of this manuscript is to present the results of 3 case studies dealing with grazing management and discuss the consequences of manipulating grazing management principles on the frequency and intensity of plan poisoning in livestock.

\section{Study Area and Methods}

\section{Study 1}

Study 1 was conducted on the 1,404-ha Texas A\&M University Experiment Station located $45 \mathrm{~km}$ south of Sonora, Texas. The rolling stony hill topography that characterizes the station is typical of the Edwards Plateau. Annual total precipitation records are extremely variable and range from 15.6 to $105.5 \mathrm{~cm}$ with an average of $60.9 \mathrm{~cm}$ during the period 1919 through 1982 .

The region's vegetation is a complex mixture of grasses, forbs, and woody species (Smeins and Merrill 1988, Huston et al. 1981). The woody plant distribution is dominated by live oak (Quercus virginiana Small), ashe juniper (Juniperus ashei Bucholz), and honey mesquite (Prospis glandulosa Torr.). Common bunchgrasses are sideoats grama (Boutelous curtipendula Michx.), Texas wintergrass ( Stipa leucotricha Trin. \& Rupr.) and threeawn (Aristida spp.). Dominant short grasses are curlymesquite (Hilaria belangeri Steud.), redgrama (Bouteloua trifida Thurb.), and hairy tridens (Erioneuron pilosum Nash).

The grazing treatments included 3 rates of stocking; a 4-pasture, 3-herd grazing system; and combinations of different kinds of livestock that were measured over 21 years. The 3 stocking rates were heavy (5.76 ha/auy), moderate ( $8.1 \mathrm{ha} /$ auy), and light (16.2 ha/auy). Continuous year-long grazing was compared with a 4pasture deferred rotation system. The combinations of animals grazed were: cattle, sheep, and goats grazed alone; cattle and goats in combination (1:1 au ratio); and cattle, sheep, and goats in combination (2:1:1 au ratio, respectively) (Merrill and Schuster 1978).

\section{Study 2}

Study 2 was conducted in the northwestern portion of the Edwards Plateau on the Texas Range Station located $34 \mathrm{~km}$ north of Ozona, Texas, at an elevation of $800 \mathrm{~m}$. The terrain is a relatively flat upland. Scattered shallow depressions and playa lake beds occur throughout the lower portion of the landscape. Precipitation occurs mostly as rainfall during spring and fall peaks. Average annual precipitation from 1941-1989 was $51.4 \mathrm{~cm}$ and ranged from 24.5 to $117.4 \mathrm{~cm}$.

Vegetation of the study area is described as an open savanna dominated by a mid-grass, tobosa, (Hiliaria mutica Benth.), and stoloniferous short-grasses, curly mesquite and buffalo grass (Buchloe dactyloides Engelm.). Honey mesquite is the dominant woody species growing on the study area.

A 14-year nonreplicated grazing study consisting of 7 treatments was implemented on the Range Station. The grazing treatments included: yearlong grazing of sheep at $10.4 \mathrm{ha} /$ auy; yearlong grazing of cattle and sheep (3:2 au equivalent ratio, respectively) at $10.4 \mathrm{ha} /$ auy; 4-pasture, 3-herd grazing system with cattle and sheep (3:2 au equivalent ratio) at 10.4 ha/auy; yearlong grazing with cattle and sheep (3:2 au equivalent ratio) at 10.4 ha/auy; 6-pasture, 1-herd grazing system with cattle and sheep (3:2 au equivalent ratio) at 10.4 ha/auy; 2-pasture, 1-herd grazing system with cattle and sheep ( $3: 2$ au equivalent ratio) at 10.4 ha/auy; and yearlong grazing of sheep at 15.2 ha/auy.

\section{Study 3}

Study 3 was conducted on high mountain summer range infested with white locoweed (Oxytropis sericea Nutt.) in northwestern Utah (Ralphs et al. 1984). Vegetation of the area is described as a sub-alpine grassland dominated by Idaho fescue (Festuca idahoensis tridentata var vaseyana $\mathrm{Rydb}$.) and mutton grass (Poa fendleriana (Steud.) Vasey). The elevation is $3,170 \mathrm{~m}$ and annual precipitation is approximately $73.5 \mathrm{~cm}$. The mountain had been heavily grazed by sheep and cattle season-long since settlement. Ironically, there was little locoweed problem during the early period of heavy grazing because the grazing pressure was so high that no animal could get enough locoweed to harm it. Locoism is a chronic poisoning that requires a fairly high intake over several weeks to cause signs of poisoning.

During the mid part of this century, grazing was controlled, animal numbers reduced, allotments were fenced, and sheep and cattle were separated. With improved management, loco was allowed to grow and poisoning problems in cattle began. There was some classical loco poisoning, but the most prevalent poisoning syndrome was high mountain brisket disease which was caused by the interaction of loco poisoning and high elevation, resulting in congestive rightsided heart failure. Calves and old cows were mostly affected.

In 1967, the allotment was put into a 4-pasture rest rotation grazing system, and 3 of the pastures were sprayed for locoweed control. There was general improvement in range condition, but the locoweed came back and caused problems by 1977 . Between 15 and $20 \%$ of the calves became sick and about half of these usually died. In dry years, up to $2 / 3$ of the calves were affected. A preliminary economic analysis estimated that the ranchers were losing a total of $\$ 30,689$ in direct and indirect livestock loss to locoweed (Barnard 1984).

In 1981 the grazing system was changed to a 3-herd, 4-pasture deferred rotation system in which the herd was evenly divided into 3 pastures for the entire season. One pasture was rested each year, and the rest treatment was rotated among the other pastures. The season was reduced from 71 to 47 days to reduce the length of exposure to locoweed, and cattle numbers were increased to maintain the same number of AUM's.

\section{Results and Discussion}

\section{Study 1}

Only 3 species of poisonous plants caused death losses to livestock. They are classified into 2 categories based on palatability and toxicology: (1) plants that are palatable and can represent a large portion of an animal's diet, but cause poisoning only during certain growth periods or forage conditions (i.e., oak and sacahuista); and (2) plants that are unpalatable and poisonous at all times (i.e., bitterweed). Bitterweed (Hymenoxys odorata DC.), a cool-season annual forb, is probably considered the most serious poisonous plant problem affecting the sheep industry in Texas (Sperry et al. 1964); it falls into the category of unpalatable and 
poisonous at all times; sheep consume the plant only when forced to do so by lack of suitable forage (Calhoun 1981). Over grazing of rangeland has increased the quantity and range of bitterweed (Landers et al. 1981). The plant vigorously grows on disturbed areas or where other vegetation is scarce.

Most bitterweed problems occur when there is sufficient soil moisture in the fall to germinate and establish the plants, followed by a drought or dry late winter and spring. Most sheep losses to bitterweed poisoning occur in the winter and early spring (Fig. 2).

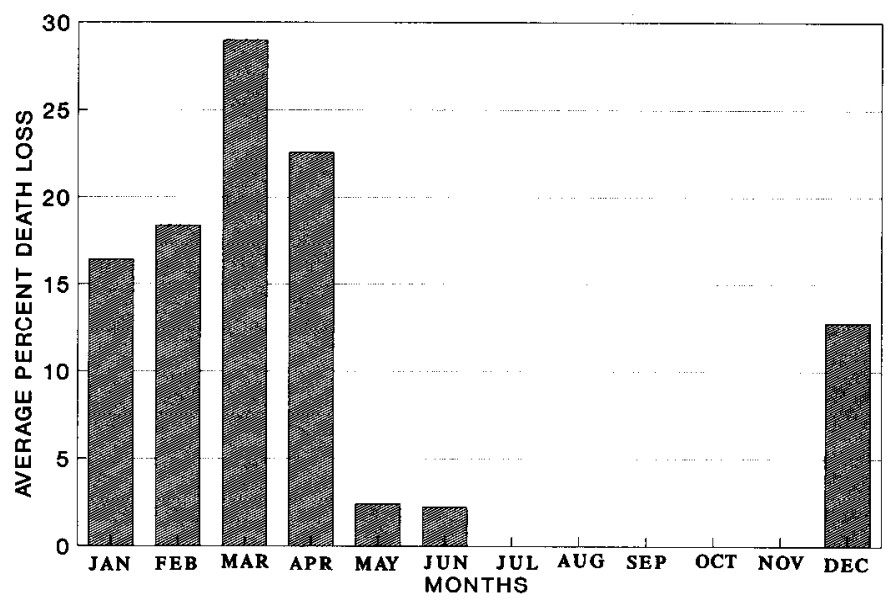

Fig. 2. Average monthly death losses $(\%)$ of sheep attributed to bitterweed poisoning on the Sonora Research Station (21 years).

Grazing management can play an important role in reducing sheep losses from bitterweed poisoning (Merrill and Schuster 1978). Stocking rate, multi-species grazing, and grazing systems all appeared to influence sheep and goat death losses due to poisonous plants (Figs. 3 and 4).

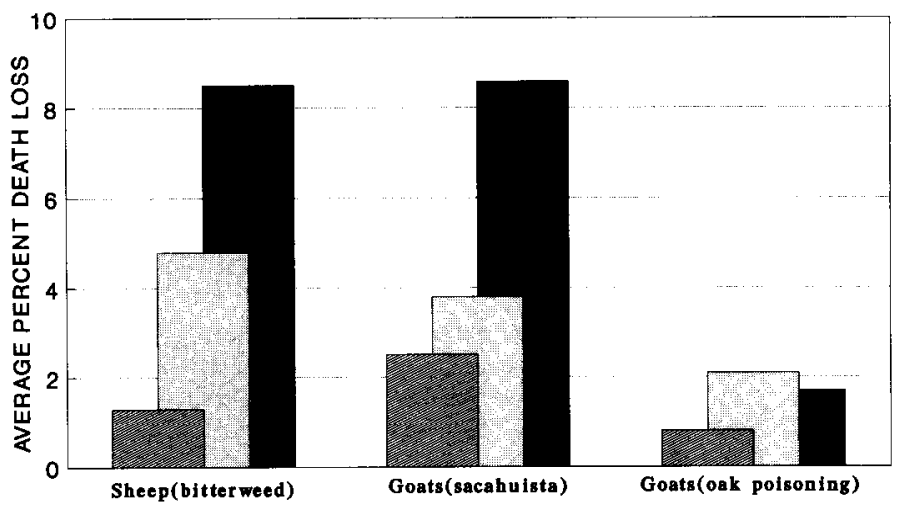

Light stock rate $\square$ Moderate stock rate Heavy stock rate

Fig. 3. Average death losses $(\%)$ of sheep and goats attributed to bitterweed, sacahuista, and oak poisoning from 3 different stocking rates on the Sonora Research Station (21 years).

Sheep death losses to bitterweed poisoning occurred in 13 of the 21 years on continuously grazed pastures heavily stocked with sheep, and only 8 years under both moderate and light stocking rates. Regardless of the stocking rate, death losses were greatest on pastures stocked with sheep only and least with the combination of livestock species in conjunction with a 4-pasture, 3-herd grazing system (Fig. 4).

Liveoak and shinoak ( $O$. pugens Liebm.) are considered low quality reserve forage plants that are relatively palatable to livestock. This is especially true for sheep, goats, and deer (Kothmann

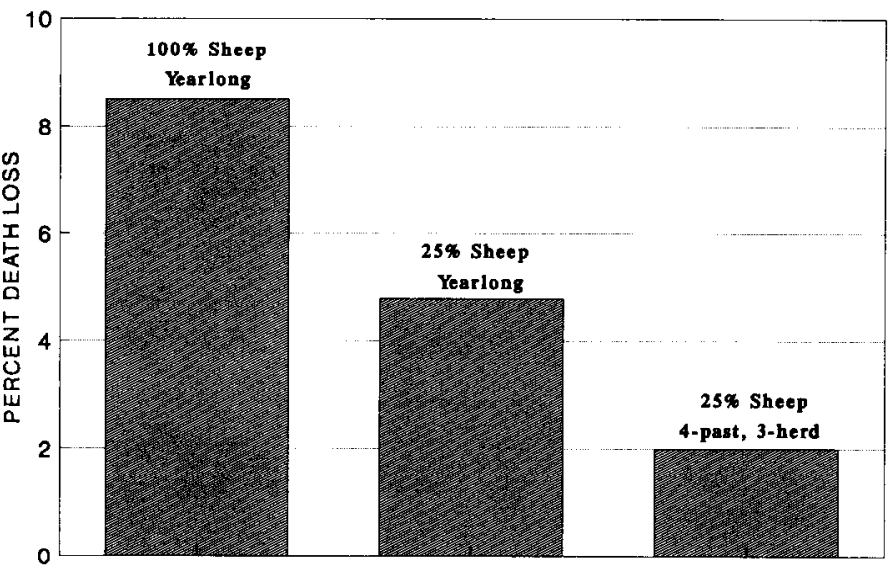

Fig. 4. Average death losses (\%) of sheep attributed to bitterweed poisoning from 3 different grazing treatments on the Sonora Reserach Station (21 years)

1968, Malechek 1970, Bryant et al. 1979, Rector 1983, Taylor 1983). However, poisoning of livestock from consumption of oak twigs, leaves and acorns represents a costly loss in the state of Texas (Reagor 1981).

In this study, death losses occurred only during the spring budding period for oaks and only goats were affected. Stocking rate, multi-species grazing, or grazing system seemed to have little effect on goat losses due to oak consumption (Fig. 3).

Sacahuista (Nolina texana wats.) is a perennial plant with grasslike leaves arising from a thick woody base. The flower buds, flowers, and fruits are toxic to cattle, sheep, and goats. The leaves of sacahuista can be safely eaten by livestock. In fact, sacahuista can be a useful reserve forage during periods of plant shortages or dormancy (Taylor 1973, Ralphs 1983). During dormant periods, sacahuista is to cattle as liveoak is to goats in the Edwards Plateau, a reserve forage of low quality.

Death losses for sacahuista appeared to be affected by stocking rate (Fig. 3). Cattle and sheep were not affected by sacahuista poisoning in this study; however, their inclusion in the grazing herd reduced goat death losses from $5 \%$ with goats only to 2.5 and $1.5 \%$ for combinations of cattle and goats and cattle, sheep, and goats, respectively.

\section{Study 2}

A major problem with extensive grazing studies is knowing the exact cause of animal death especially when poisonous plants are present. In this study, not all animals were autopsied, but most deaths occurred during periods of the year when bitterweed was known to be a problem.

The all-sheep pasture stocked at 10.4 ha/auy and grazed yearlong had the largest death loss (Fig. 5). The lowest death loss of ewes occurred from the $40 \%$ sheep pasture stocked at 15.2 ha/auy. Sheep death losses from continuous yearlong grazing treatments averaged $5.2 \%$ vs $3.7 \%$ for grazing treatments with some type of grazing system.

Since treatments were not replicated for this study, no statistical analysis for significant differences were conducted; however, the results tended to support other data that indicate: (1) death losses can be reduced if combinations of animal species are grazed together rather than a single species; (2) reduced stocking rate will reduce death losses and; (3) grazing systems help reduce death losses at moderate stocking rates (Merrill and Schuster 1978, Bounds 1984, Ueckert and Calhoun 1984). 
